\title{
Breast Fat Necrosis
}

National Cancer Institute

\section{Source}

National Cancer Institute. Breast Fat Necrosis. NCI Thesaurus. Code C3661.

Localized necrosis of the adipose tissue in the breast. Clinically, it may present as a mass.

Causes include injury, surgical procedures, and radiation treatment. 